\title{
Intensitas Dzikir Ratib Al-Haddad dan Kecerdasan Spiritual Santri
}

\author{
Mamay Maesaroh \\ Jurusan Bimbingan Konseling Islam, UIN Sunan Gunung Djati, Bandung \\ *Email : mamaym422@gmail.com
}

\begin{abstract}
This paper reveals about the intensity of dhikr ratib al-haddad, spiritual intelligence of santri, and the influence of the dhiker ratib al-haddad intensity to the spiritual intelligence of Pondok Pesantren santri Mathla'unnajah Ujungjaya Sumedang. The method used is survey method with quantitative approach through simple correlation and regression analysis. Data collection techniques were conducted by observation, questionnaire, and documentation. The results obtained from this study indicate that the intensity value of dhikr ratib al-haddad is 0.79 or $79 \%$ of each item statement with high categorization. While the value of spiritual intelligence of santri of 0.80 or $80 \%$ of each item statement with a very bigh categorization. In addition, based on the analysis of coefficient of determination can be seen that the percentage of the influence intensity of dhiker ratib al-haddad to the spiritual intelligence of santri is 0.246 or $24.60 \%$ and 0.754 or $75.40 \%$ other influenced by other variables outside the variable $X$.
\end{abstract}

Keywords: Intensity of Dhiker Ratib Al-Haddad, Spiritual Intelligence, Santri

\begin{abstract}
ABSTRAK
Tulisan ini mengungkapkan tentang intensitas dzikir ratib al-haddad, kecerdasan spiritual santri, dan pengaruh intensitas dzikir ratib al-haddad terhadap kecerdasan spiritual santri Pondok Pesantren Mathla'unnajah Ujungjaya Sumedang. Metode yang digunakan adalah metode survei dengan pendekatan kuantitatif melalui analisis korelasi dan regresi sederhana. Teknik pengumpulan data dilakukan dengan observasi, kuesioner, dan dokumentasi. Hasil penelitian menunjukkan bahwa nilai intensitas dizkir ratib al-haddad yaitu 0.79 atau $79 \%$ dari setiap item pernyataan dengan kategorisasi tinggi. Sedangkan nilai kecerdasan spiritual santri sebesar 0.80 atau $80 \%$ dari setiap item pernyataan dengan kategorisasi sangat tinggi. Selain itu, berdasar pada analisis koefisien
\end{abstract}


determinasi dapat diketahui bahwa besarnya presentase pengaruh intensitas dzikir ratib al-haddad terhadap kecerdasan spiritual santri yaitu 0.246 atau $24.60 \%$ dan 0.754 atau $75.40 \%$ lainnya dipengaruhi variabel lain di luar variabel $\mathrm{X}$.

Kata Kunci : Intensitas Dzikir Ratib Al-Haddad, Kecerdasan Spiritual, Santri

\section{PENDAHULUAN}

Manusia merupakan makhluk spiritual yang tidak bisa terlepas dari kecerdasan spiritual. Saat ini manusia hidup di kegalauan peradaban modern dalam menemukan bentuk terbaiknya. Peradaban modern ini dapat membuat sebagian besar orang tidak berkembang baik secara psikologis dan sehat secara agamis. Beberapa fenomena yang terjadi setidaknya bisa dijadikan sebagai ukuran, diantaranya ketika terjadi krisis ekonomi, kepercayaan, dan politik yang menyebabkan terjadinya konflik sosial di berbagai daerah. Seperti konflik antar warga masyarakat, tawuran pelajar, perjudian, kasus narkoba, perampokan dan lain-lain. Ketika kecerdasan spiritual kosong dalam diri seseorang maka perannya digantikan oleh emosi dan kesombongan yang mengakibatkan kehancuran.

Peradaban modern ini membawa dampak luar biasa terhadap masyarakat. Selain membawa dampak positif, peradaban modern juga membawa dampak negatif. Beberapa dampak positif dari peradaban modern adalah semakin mudahnya seseorang mendapatkan akses pengetahuan atau akses ke belahan dunia karena banyak alat transportasi. Di sisi lain, manusia cenderung mengikuti hawa nafsu tanpa meikirkan terlebih dahulu konsekuensi atas perbuatannya. Perilaku individualis yang terjadi di masyarakat modern, terutama masyarakat perkotaan telah merenggut nikai-nilai empati antara satu sama lain. Oleh karena itu, penting bagi seseorang memiliki kecerdasan spiritual agar terhindar dari berbagai hal negatif yang dapat merugikan dirinya.

Cita-cita pesantren adalah meneruskan estafet perjuangan Nabi. Begitupun idealitas pesantren sebagai basic pertahanan ajaran-ajaran Islam. Namun realitanya justru berbalik. Ternyata prisnisp-prinsip pesantren mulai bergeser di kalangan santri, khususnya para remaja. Pergeseran ini disebabkan kecenderungan mereka mengikuti budaya luar yang tak sejalan dengan prinsip pesantren. Pelanggaran atau perilaku negatif santri kerap bermuara pada budaya tersebut, seperti melihat konser musik, kekerasan fisik, pencurian, pacaran, dan lain-lain. Tetapi tidak semua santri melakukan kenakalan-kenakalan semacam itu.

Kontrol diri yang lemah akan menambah daftar kenalakan santri yang tidak bisa mempelajari dan membedakan tingkah laku yang dapat diterima dengan yang tidak dapat diterima. Begitupun bagi mereka yang telah mengetahui 
perbedaan dua tingkah laku tersebut, namun tidak bisa mengembangkan kontrol diri untuk bertingkah laku sesuai dengan ilmu pengetahuannya.

Peristiwa tersebut menunjukkan bahwa pentingnya santri memiliki nilai kecerdasan spiritual yang tinggi agar bisa mengendalikan dirinya dengan baik dan mengaplikasikan pengetahuan yang dipelajarinya di pesantren sehingga dapat hidup lebih bermakna.

Upaya untuk meningkatkan kecerdasan spiritual dapat dilakukan dengan berbagai cara, salah satunya dengan pembacaan dzikir.

Diantara manfaat dzikir ialah mendapatkan ketenangan jiwa, memperoleh ampunan serta pahala dari Allah, melunakkan hati, menghindarkan diri dari bahaya, menumbuhkan energi akhlak dan mampu membedakan antara yang hak dan bathil. Kemampuan untuk membedakan antara yang hak dan yang bathil ini terdapat dalam surat Al-'Araaf ayat 201 sebagai berikut:

Artinya:

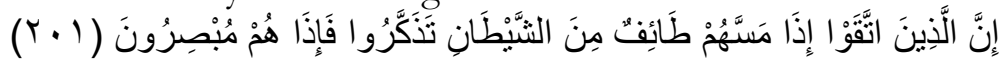

"Sesungguhnya orang-orang yang bertakwa bila mereka ditimpa was-was dari syaitan, mereka ingat kepada Allah, maka ketika itu juga mereka melihat kesalahan-kesalahannya." (Kemenag, 2014: 176)

Berdasarkan beberapa manfaat dzikir yang telah dijelaskan di atas memiliki kesinambungan dengan kecerdasan spiritual. Manfaat tersebut dihasilkan dari aktifitas dzikir yang secara tidak langsung membuat kecerdasan seseorang meningkat, karena dengan sering berdzikir seseorang akan mampu bersikap lebih baik dan bijaksana.

Hasil penelitian sebelumnya yang dijadikan perbandingan karya ilmiah tidak terlepas dari topik penelitian terdahulu yangitu Skripsi yang disusun oleh Oktaf Giar Purnomo mahasiswa Prodi Bimbingan Konseling Islam Jurusan Dakwah STAIN Purwokerto tahun 2014 yang berjudul Drikrul Ghofilin sebagai terapi penyakit hati (Studi kasus di Pondok Pesantren Al-Falah Jatilawang Banyumas). Membahas tentang pelaksanaan drikrul ghofilin sebagai terapi penyakit hati dan pengaruh drikrul ghofilin bagi para santri di Pondok Pesantren Al-Falah Jatilawang Banyumas. Drikerul ghofilin dapat menajamkan kekuatan ekstradimensional atau dalam bahasa tasawuf adalah dunia metafisika pikiran manusia sampai pada tingkatan tertentu, sehingga ia mampu menerima informasi yang sebelumnya jauh melampaui pemahamannya.

Persamaan dari penelitian ini dengan penelitian sebelumnya sama-sama membahas pengaruh dzikir terhadap santri yang telah menjadi suatu program kegiatan yang dilakukan di pondok pesantren, sehingga hasil yang dicapai samasama cukup signifikan. Perbedaan dari penelitian terdahulu dengan penelitian ini, 
materi dzikir yang dikaji berbeda. Penelitian sebelmunya mengkaji dzikerul ghafilin sedangkan penelitian ini mengkaji dzikir ratib al-haddad.

Adapun penelitian terdahulu lainnya yang dilakukan oleh Noupal (2018) mengungkapkan bahwa maraknya pembacaan zikir Ratib tidak menunjukkan bahwa tarekat haddadiyah dianut masyarakat Palembang; sebab zikir Ratib Haddad lebih dianggap sebagai zikir umum yang pembacaannya boleh dilakukan oleh siapa saja. Selanjutnya penelitian yang dilakukan oleh Rahmawati (2016) ditemukan bahwa kegiatan yang dilaksanakan di Rumah TahfidzQu Deresan Putri adalah berbasis kegiatan keagamaan. Berdasarkan data yang diperoleh bahwa pelaksanaan kegiatan di Rumah TahfidzQu Deresan Putri dapat peneliti klasifikasikan menurut waktu pelakasanaannya menjadi dalam tiga bagian, pertama yaitu kegiatan harian yang meliputi menghafal al-quran, salat berjamaah diawal waktu, salat tahajud, salat rawatib, salat duha, puasa sunah, sedekah, zikir dan diniyah. Kedua, kegiatan mingguan, yang meliputi; membaca surah al-Kahfi, membaca surah al-Waqi'ah, Kajian Hadis, muhadoroh dan tasmi', ketiga, kegiatan bulanan yaitu Ta'lim For Kids.

Pondok Pesantren Mathla'unnajah Ujungjaya Sumedang merupakan sebuah pondok pesantren yang berada di jalan Pesantren Rt.03 Rw.03 Desa Ujungjaya Kecamatan Ujungjaya Kabupaten Sumedang. Pondok Pesantren Mathla'unnajah memiliki salah satu program berupa pembacaan dzikir ratib alhaddad. Dzikir ratib al-haddad merupakan salah satu dzikir yang diwajibkan oleh pendiri Pondok Pesantren Mathla'unnajah KH. Abdurrahim Musa (alm) sekaligus wasiat dari guru besar beliau Al Habib dari Hadramaut Yaman.

Observasi sementara menunjukkan bahwa di Pondok Pesantren Mathla'unnajah banyak para santri yang sering mengikuti pembacaan dzikir ratib al-haddad. Namun, pelanggaran-pelanggaran terhadap peraturan masih saja terjadi. Padahal salah satu dari keutamaan dzikir adalah dapat membedakan antara yang hak dan yang bathil. Apakah dzikir yang dilakukan oleh para santri di Pondok Pesantren Mathla'unnajah ini benar-benar berkualitas dan berpengaruh terhadap kecerdasan spiritualnya serta mampu menjadi perisai dari berbagai penyimpangan dan menjadi pengendali bagi arus perkembangan zaman. Sehingga para santri menyadari bahwa Allah SWT senantiasa mengawasinya dan menjadikannya sebagai golongan dari muttaqin di tengah arus globalisasi dan modernisasi ataukah tidak. Berdasarkan fenomena di atas, penulis tertarik untuk mengetahui dan meneliti "Pengaruh Intensitas Dzikir Ratib Al-Haddad terhadap Kecerdasan Spiritual Santri” di Pondok Pesantren Mathla'unnajah Ujungjaya Sumedang.

Tulisan ini bermaksud mengungkapkan tentang intensitas dzikir ratib alhaddad, kecerdasan spiritual santri, dan pengaruh intensitas dzikir ratib alhaddad terhadap kecerdasan spiritual santri Pondok Pesantren Mathla'unnajah Ujungjaya Sumedang. Berpijak pada tujuan di atas, tulisan ini diharapkan 
memiliki manfaat secara teoritis dan dapat menjadi tambahan literatur bagi pengembangan pengetahuan bimbingan konseling islam dalam ranah psikoterapi islam khususnya mengenai dzikir. Secara praktis diharapkan dapat memberikan informasi kepada semua pihak tentang pengaruh intensitas dzikir ratib al-haddad terhadap kecerdasan spiritual santri yang dilakukan di Pondok Pesantren Mathla'unnajah Ujungjaya Sumedang.

Metode yang digunakan dalam penelitian ini adalah metode survei dengan pendekatan kuantitatif melalui analisis korelasi dan regresi sederhana. Informasi dikumpulkan menggunakan kuesioner dengan jumlah sampel yang ditentukan. Analisis ini akan digunakan dalam menguji besarnya pengaruh yang ditunjukan oleh koefisien korelasi antar variable intensitas dzikir ratib al-haddad terhadap kecerdasan spiritual santri.

\section{LANDASAN TEORITIS}

Teori yang dijadikan landasan dalam penelitian ini adalah teori dzikir, ratib al haddad, kecerdasan spiritual dan santri. Pembahasan teori pertama yaitu dzikir,

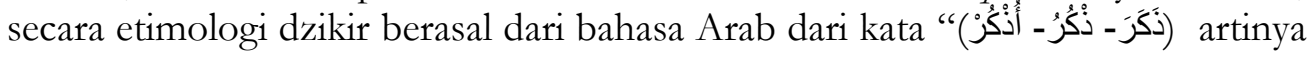
ingat-mengingat-ingatlah, dapat juga berarti memperhatikan, mengenang, mengambil pelajaran, mengenal atau mengerti dan mengingat-ingat" (Amin, 2008: 11). Sedangkan secara terminologi dzikir yaitu usaha manusia untuk mendekatkan diri pada Allah dengan cara mengingat Allah dan keagungan-Nya. Adapun realisasi untuk mengingat Allah yaitu dengan cara memuji-Nya, membaca firman-Nya dan memohon kepada-Nya (Al Islam, 1987: 187).

Seperti yang dikatakan oleh Al Ghazali:

"Dzikrullah berarti ingatnya seseorang bahwa Allah mengamati seluruh tindakan dan pikirannya" Jadi dzikir Allah bukan sekedar mengingat suatu peristiwa, namun mengingat Allah dengan sepenuh keyakinan akan kebesaran Tuhan dengan segala sifat-Nya serta menyadari bahwa dirinya berada dalam pengawasan Allah, seraya menyebut nama Allah dalam hati dan lisan (Ansori, 2003: 19).

Menurut Anshori dzikir bermanfaat mengontrol perilaku. Pengaruh yang ditimbulkan secara konstan akan mampu mengontrol perilaku seseorang dalam kehidupan sehari-hari. Seseorang yang melupakan dzikir atau lupa kepada Tuhan, terkadang tanpa sadar dapat berbuat maksiat, namun mana kala ingat kepada Tuhan kesadaran akan dirinya sebagai hamba Tuhan akan muncul kembali (Anshori, 2003: 33).

Kedua, ratib al haddad. Makna kata ratib diambil dari kata Rotaba Yartubu Rotban Rutuuban atau Tarottaba Yatarottabu Tarottuban, yang berarti tetap atau tidak bergerak. Jadi kata Ratib menurut bahasa artinya kokoh atau yang tetap. 
Sedangkan menurut istilah, Ratib diambil dari kata Tartiibul-Harsi Lil-Himaayah (penjagaan secara rutin untuk melindungi sesuatu atau seseorang).

Menurut "Alawi Al-Haddad yang dimaksud dengan "Ratib" ialah himpunan sejumlah ayat-ayat al-Qur'an dan untaian kalimat-kalimat dzikir yang lazim diwiridkan atau diucapkan berulang-ulang sebagai salah satu bentuk ibadah mendekatkan diri kepada Allah SWT. Sebagian besar kaum muslimin, khususnya di Indonesia berkeyakinan betapa besar manfaat mengamalkan Ratib AlHaddad, untuk kemantapan iman dan akidah tauhid maupun kemaslahatan hidup di dunia dan akhirat. Ada beberapa "Ratib" yang disusun oleh beberapa ulama ash-shalihin. Namun, ratib yang disusun oleh Imam Al-Haddad adalah yang termasyhur diamalkan oleh kaum muslim dan muslimat di berbagai negeri, di mesjid-mesjid, di suaru-surau, si kampung-kampung dan di tempat permukiman lainnya. (Alawy Al-Haddad, 1999: 8).

Adapun yang dimaksud adalah Habib Abdullah Al-Haddad cucu Nabi Muhammad SAW dari Sayyidah Fatimah ke Sayyidina Husain sampai ke Syaikh 'Alwi Al-Haddad (1044-1132 H) yang lahir di pinggir kota Tarim (Hadramaut). Beliau dikenal sebagai salah seorang sufi yang cukup berpengaruh, beliau dianggap sebagai pencetus tarekat al-Hadadiyyah. Syaikh Al-Haddad ukup dikenal luas oleh masyarakat Indonesia, terutama masyarakat muslim tradisional mengenal beliau sebagai salah seorang tokoh besar yang dianggap telah berjasa dalam membimbing umat ke jalan yang lurus (Idrus Abdullah Al-Kaff, 2003: 17).

Setiap ayat, doa, dan nama Allah yang disebutkan di dalam ratib ini diambil dari bacaan Al Quran dan Hadis Rasul SAW. bilangan bacaan di setiap doa dibuat sebanyak tiga kali, karena itu adalah bilangan ganjil (witir). Semua ini berdasarkan arahan dari al Habib Abdullah bin Alwi al Haddad sendiri. Dari beberapa doa-doa dan dzikir-dzikir yang beliau susun, Ratib al Haddad inilah yang paling terkenal dan masyhur. Ratib al Haddad disusun berdasarkan inspirasi, pada malam lailatul Qodar 27 Ramadan 1071 H. Setelah al Habib Abdullah bin Alwi al Haddad berangkat menunaikan ibadah Haji, Ratib al Haddad mulai dibaca di Mekkah dan Madinah. Al Habib Ahmad bin Zain al Habsyi berkata, "Barang siapa yang membaca Ratib al Haddad dengan penuh keyakinan dan iman, ia akan mendapat sesuatu yang di luar dugaannya".

Berdasarkan penjelasan di atas, istilah ratib ini sebenarnya sering digunakan di daerah Hadramaut Yaman namun telah tersebar juga ke negara tertentu seperti Afrika, Brunei, Singapura, India, Malaysia, Indonesia dan sebagainya. Dengan demikian, dzikir ratib al-haddad adalah kumpulan dzikirdzikir atau wirid yang berasal dari al Quran dan hadits dengan rata-rata jumlah bilangan bacaan di setiap doa dibuat sebanyak tiga kali, karena itu adalah bilangan ganjil (witir). Ratib ini memiliki keutamaan dan rahasia yang luar biasa 
sehingga sangat baik untuk dibaca dan diamalkan setiap hari, baik pada waktu pagi dan malam hari.

Ketiga, kecerdasan spiritual. Kecerdasan atau intelligence memiliki arti yang sangat luas. Dalam Kamus Besar Bahasa Indonesia cerdas diartikan sebagai perihal cerdas (sebagai kata benda), atau sempurna perkembangan akal budinya (untuk berfikir, mengerti, dsb) (Kebudayaan, 1989: 208). Pendapat lain mengatakan kecerdasan (intelligence) adalah hal-hal yang menunjukkan kemampuan untuk menerima, memahami, dan menggunakan simbol-simbol sehingga mampu menyelesaikan masalah-masalah yang abstrak (Kurniasih, 2010: 13). Sedangkan "spirit" berasal dari bahasa latin yaitu spirtus yang berarti luas atau dalam, keteguhan hati, atau keyakinan, energi atau semangat dan kehidupan (Desmita, 2010: 264). Dengan demikian, dapat disimpulkan yang dimaksud dengan kecerdasan spiritual adalah kesempurnaan menyesuaikan diri terhadap perkembangan kejiwaan, rohani, batin, mental serta moral diri seseorang.

Danah Zohar dan Ian Marshall berpendapat bahwa (2007: 4):

Kecerdasan spiritual adalah kecerdasan untuk menghadapi persoalan makna atau value, yaitu kecerdasan untuk menempatkan perilaku dan hidup manusia dalam konteks makna yang lebih luas dan kaya, kecerdasan untuk menilai bahwa tindakan atau jalan hidup seseorang lebih bermakna dibandingkan dengan yang lain. SQ adalah landasan yang diperlukan untuk memfungsikan IQ dan EQ secara efektif bahkan SQ merupakan kecerdasan tertinggi manusia.

Dari kutipan di atas dapat dipahami bahwa kecerdasan spiritual adalah kecerdasan yang paling tinggi, bahkan kecerdasan inilah yang dipandang berperan memfungsikan dari kecerdasan IQ dan EQ. Sebelum kecerdasan spiritual ditemukan, para ahli sangat bangga dengan temuan mereka tentang IQ dan EQ sehingga muncul paradigma di kalangan masyarakat bahwa otak merupakan segalanya, padahal nyatanya tidak demikian.

Ketiga, santri. Asal usul kata "santri" dalam pandangan Nurcholis Madjid (1999: 19-20) dapat dilihat dari dua pendapat. Pertama, pendapat yang mengatakan bahwa "santri" berasal dari perkataan "sastri", sebuah kata dari bahasa Sansekerta yang artinya melek huruf. Kedua, pendapat yang mengatakan bahwa perkataan santri sesungguhnya berasal dari bahasa Jawa yaitu dari kata "cantrik", berarti seseorang yang selalu mengikuti seorang guru itu pergi menetap.

Zamakhsyari Dhofier (2011: 88) menyebutkan bahwa pengertian santri adalah sebutan yang dipakai dalam lingkungan orang-orang pesantren, seorang alim hanya bisa disebut kyai bilamana memiliki pesantren dan santri yang tinggal dalam pesantren bermaksud untuk mempelajari kitabkitab Islam klasik. Oleh karena itu, santri merupakan elemen penting 
dalam suatu lembaga pesantren.

\section{HASIL DAN PEMBAHASAN}

Penelitian ini dilakukan di Pondok Pesantren Mathla'unnajah Ujungjaya Sumedang. Pondok pesantren ini merupakan sebuah pondok pesantren yang berada di jalan Pesantren Rt. 03 Rw. 03 Desa Ujungjaya Kecamatan Ujungjaya Kabupaten Sumedang. Santri Pondok Pesantren Mathla'unnajah terdiri dari usia 11-20 tahun sampai dengan tahun ajaran sekarang jumlah santri di Pondok Pesantren Mathla'unnajah sebanyak 90 orang santri yang berasal dari jawa dan luar jawa.

Pondok pesantren salah satu lembaga yang bertujuan untuk memberikan pemahaman nilai-nilai ketuhanan dan mengajarkan sikap religius kepada santri memiliki peran penting dalam menghasilkan generasi penerus bangsa yang memiliki nilai kecerdasan spiritual yang tinggi. Salah satu program yang dilaksanakan di Pondok Pesantren Mathla'unnajah Ujungjaya Sumedang selain dari bimbingan keagamaan, pengajian kitab kuning, muhadoroh, pelatihan marawis juga terdapat program pembacaan dzikir ratib al-haddad. Pembacaan dzikir ratib al-haddad ini merupakan salah satu amanat dari pendiri pondok pesantren, yaitu KH. Abdurrahim Musa (alm) sejak tahun 1992. Dzikir ratib alhaddad ini juga merupakan perintah dari guru beliau yaitu Habib Abdullah sehingga beliau mewajibkan kepada seluruh santri untuk senantiasa mendawamkan dzikir ini.

Fenomena yang terjadi di Pondok Pesantren Mathla'unnajah, seiring perkembangan usia identitas santri sedikit demi sedikit mulai terkikis, lebih-lebih pada remaja seperti tidak lagi bersikap tawadlu pada guru dan orang-orang sekitarnya terutama orang tua, tutur kata yang kasar, suka urakan dan rendahnya sikap menghormati. Diperparah lagi karena pengaruh pesatnya laju budaya modern dan informasi tanpa ada filter ketat. Obyek perhatian santri dalam berpikir, bersikap dan bertindak juga mulai bergeser mengikuti aturan main remaja sebaya yang berkembang di lingkungan eksternal pesantren. Kontrol diri yang lemah akan menambah daftar "kenakalan" santri yang tidak bisa mempelajari dan membedakan tingkah laku yang dapat diterima dengan yang tidak dapat diterima. Begitupun bagi mereka yang telah mengetahui perbedaan dua tingkah laku tersebut, namun tidak bisa mengembangkan kontrol diri untuk bertingkah laku sesuai dengan ilmu pengetahuannya. Peristiwa terebut menunjukkan bahwa pentingnya santri memiliki nilai kecerdasan spiritual yang tinggi agar bisa mengendalikan dirinya dengan baik dan mengaplikasikan pengetahuan yang dipelajarinya di pesantren sehingga dapat hidup lebih bermakna.

Berdasarkan fenomena tersebut diperkuat dengan penelitian sebelumnya mengenai spiritualitas cyberspace ; interplay post-sainsteknologi dan filosofi 
spiritualitas sains dakwah, bahwa dunia maya telah membawa perubahan radikal dalam semua aspek kemanusiaan termasuk aspek spiritual. Meskipun dunia maya memberikan manfaat terhadap spiritualitas, dunia maya juga sebenarnya telah mengakibatkan paradoks beberapa rohani. Secara paradoks dunia maya telah difungsikan sebagai komunikasi agama atau agama itu sendiri, baik sebagai saluran enegri spiritual atau spiritualitas itu sendiri (Wahyudin, 2015).

Diperoleh nilai hasil kriteria penilaian intensitas dzikir ratib al-haddad diperoleh hasil rata-rata presentase sebesar $79 \%$. Hal ini menunjukan bahwa intensitas dzikir ratib al-haddad berada dalam keadaan baik sesuai dengan jawaban yang diberikan oleh responden yang menghasilkan nilai $79 \%$ yang berada dalam skala kategori tinggi.

Selanjutnya diperoleh nilai hasil kriteria penilaian kecerdasan spiritual santri Pondok Pesantren Mathla'unnajah Ujungjaya Sumedang diperoleh hasil rata-rata presentase sebesar $80 \%$. Hal ini menunjukan bahwa kecerdasan spiritual santri berada dalam keadaan sangat baik sesuai dengan jawaban yang diberikan oleh responden yang menghasilkan nilai $80 \%$ yang berada dalam skala kategori sangat tinggi.

Berdasarkan hasil output SPSS (Statistical Pakcage for Social Science) 20.0 for windows pada tabel di atas diperoleh $\mathrm{Pv}(0.955) \geq 0.05$. Maka $\mathrm{H}_{0}$ diterima, nilai residual tersebut normal atau dapat disimpulkan bahwa uji normalitas untuk kuesioner tersebut terpenuhi dan dapat disimpulkan bahwa data tersebut berdistribusi normal.

Berdasarkan uji linearitas karena $\mathrm{Pv}<0.05$ maka $\mathrm{H}_{0}$ ditolak sehingga model regresi linear sederhana dapat digunakan dalam memprediksi peningkatan kecerdasan spiritual santri Pondok Pesantren Mathla'unnajah Ujungjaya Sumedang yang dipengaruhi intensitas dzikir ratib al-haddad. Konstanta (a) = 26.680 artinya apabila intensitas dzikir ratib al-haddad sama dengan nol (tidak ada perubahan ), maka kecerdasan spiritual santri sebesar 0.442. Koefisien Regresi Intensitas Dzikir Ratib Al-Haddad (b) $=0.442$. Artinya koefisien regresi postif ( searah ) sebesar 0.442. Jika intensitas dzikir ratib al-haddad meningkat 1 satuan, maka kecerdasan spiritual santri sebesar 0.442 yang berarti jika intensitas dzikir ratib al-haddad naik sebesar 1,329 maka kecerdasan spiritual santri akan naik sebesar 0.442

Nilai t hitung untuk variabel intensitas dzikir ratib al-haddad (X) adalah sebesar 4.611 dan nilai $\mathrm{t}$ tabel adalah 2.027 , sehingga $\mathrm{t}$ hitung $\geq \mathrm{t}$ tabel $(4.611 \geq$ 2.027) dengan tingkat signifikasi berdasarkan perhitungan SPSS (Statistical Pakcage for Social Science) 20.0 for windows diperoleh $0.000 \leq 0.05$. Karena $\mathrm{Pv}<$ 0.05 maka $\mathrm{H}_{0}$ ditolak sehingga Terdapat pengaruh positif intensitas dzikir ratib al-haddad terhadap kecerdasan spiritual santri Pondok Pesantren Mathla'unnajah Ujungjaya Sumedang. 
Berdasarkan perhitungan uji regresi sederhana, nilai $\mathrm{R}$ merupakan simbol dari nilai koefisien korelas. Nilai korelasi yang didapat sebesar 0.496. Nilai ini dapat diinterpretasikan bahwa hubungan kedua variabel penelitian ada pada kategori cukup kuat. Melalui tabel ini juga diperoleh nilai R Square atau koefisien determinasi (KD) yang menunjukan berapa besar model regresi yang dibentuk oleh interaksi variabel bebas dan variabel terikat. Nilai koefisien determinasi (KD) yang diperoleh adalah $0.246 \times 100 \%=24.60 \%$ yang dapat ditafsirkan bahwa variabel bebas atau variabel $\mathrm{X}$ (Intensitas Dzikir Ratib Al-Haddad) memiliki pengaruh sebesar $24.60 \%$ terhadap variabel terikat atau variabel $\mathrm{Y}$ (Kecerdasan Spiritual Santri) dan 75.40\% lainnya dipengaruhi oleh faktor-faktor lain di luar variabel X. Maka dapat disimpulkan pengaruh intensitas dzikir ratib al-haddad terhadap kecerdasan spiritual santri memiliki pengaruh rendah, karena posisi nilai berada pada interval 0.20-0.39 (Sugiono, 2012: 186).

Hasil penelitian ini menemukan kategorisasi intensitas dzikir ratib alhaddad, kecerdasan spiritual santri dan pengaruh intensitas dzikir ratib al-haddad terhadap kecerdasan spiritual santri di Pondok Pesantren Mathla'uunajah Ujungjaya Sumedang.

\section{Intensitas Dzikir Ratib Al-Haddad}

Untuk mendapatkan hasil yang akurat peneliti membagikan kuesioner kepada seluruh santri Pondok Pesantren Mathla'unnajah Ujungjaya Sumedang yang mengikuti kegiatan dzikir ratib al-haddad dengan menentukan terlebih dahulu indikator intensitas dzikir ratib al-haddad. Adapun indikatornya yaitu: frekuensi kegiatan, motivasi, kemauan, perhatian saat mengikuti dzikir, spirit of changes, dan efek. Dari beberapa indikator tersebut, peneliti membuat 11 pernyataan untuk mengukur intensitas dzikir ratib al-haddad.

Dalam penentuan kategorisasi skala perhitungan hasil kuesioner yang telah diisi oleh setiap santri Pondok Pesantren Mathla'unnajah Ujungjaya Sumedang, jumlah skor ideal untuk seluruh item pernyataan yaitu $5 \times 67=335$ untuk jawaban sangat setuju, $4 \times 67=268$ untuk jawaban setuju, $3 \times 67=201$ untuk jawaban netral, 2 × $67=134$ untuk jawaban tidak setuju, dan $1 \times 67=67$ untuk jawaban sangat tidak setuju.

Untuk interpretasi kategorisasi skala perhitungan nilai intesitas dzikir ratib al-haddad, peneliti menggunakan skala sebagai berikut:

Tabel 1.1

\section{Kategorisasi Skala Perhitungan}




\begin{tabular}{lll}
\hline Rentang Skor & Presantase Skor & Kategorisasi \\
\hline $269-335$ & $80-100 \%$ & Sangat Tinggi \\
$202-268$ & $60-79 \%$ & Tinggi \\
$135-201$ & $40-59 \%$ & Cukup Tinggi \\
$68-134$ & $20-39 \%$ & Rendah \\
$0-67$ & $0-19 \%$ & Sangat Rendah \\
\hline
\end{tabular}

Berdasarkan kuesioner yang telah peneliti bagikan kepada seluruh responden yang berjumlah 67 santri, pada kuesioner variabel $\mathrm{X}$ penulis memberikan pernyataan yang berkaitan dengan intensitas dzikir ratib al-haddad disesuaikan pada aspek, dan indikator intensitas. Namun, untuk penomoran kuesioner penulis membaginya secara acak tidak tergantung pada urutan aspek atau indikatornya.

Hasil perhitungan dari setiap pernyataan secara akumulatif dapat dihitung nilai rata-rata seluruh pernyataan variavel $\mathrm{X}$ yaitu intensitas dzikir ratib al-haddad sebagai berikut:

$$
\begin{gathered}
\bar{X}=\frac{X_{1}+X_{2}+X_{3}+X_{4}+X_{5}+\ldots \ldots X_{n}}{n} \\
\bar{X}=\frac{89+78+70+78+75+71+83+79+80+84}{10} \\
\bar{X}=\frac{787}{10} \\
\bar{X}=78.7=79
\end{gathered}
$$

Berdasarkan perhitungan tersebut, nilai rata-rata variabel $\mathrm{X}$ atau intensitas dzikir ratib al-haddad yaitu sebesar $79 \%$. Dengan demikian, dapat disimpulkan bahwa nilai intensitas dzikir ratib al-haddad santri Pondok Pesantren Mathla'unnajah Ujungjaya Sumedang sebesar $79 \%$ termasuk pada skala kategorisasi tinggi.

\section{Kecerdasan Spiritual Santri}

Sebelum mengukur kecerdasan spiritual santri, terlebih dahulu peneliti menentukan aspek kecerdasan spiritual sebagaimana yang dipaparkan oleh Ary Ginanjar Agustian (dalam Tasmara, 2011: 189) bahwa aspek kecerdasan spiritual yaitu: shiddiq, istiqamah, fathanah, amanah, dan tablig. Berdasarkan kuesioner yang 
telah peneliti bagikan kepada seluruh responden yang berjumlah 67 santri, pada kuesioner variabel $\mathrm{Y}$ penulis memberikan pernyataan yang berkaitan dengan kecerdasan spiritual santri disesuaikan pada aspek, dan indikator kecerdasan spiritual. Namun, untuk penomoran kuesioner peneliti membaginya secara acak tidak tergantung pada urutan aspek atau indikatornya.

Berdasarkan perhitungan setiap pernyataan dari responden, secara akumulatif dapat dihitung nilai rata-rata seluruh pernyataan variavel $\mathrm{Y}$ yaitu kecerdasan spiritual santri sebagai berikut:

$$
\begin{gathered}
\bar{X}=\frac{X_{1}+X_{2}+X_{3}+X_{4}+X_{5}+\ldots \ldots . . X_{n}}{n} \\
\bar{X}=\frac{85+75+77+89+90+92+82+71+76+71+76}{11} \\
\bar{X}=\frac{884}{11} \\
\bar{X}=80.36=80
\end{gathered}
$$

Berdasarkan perhitungan tersebut, nilai rata-rata variabel $Y$ atau kecerdasan spritual yaitu sebesar 80\%. Dengan demikian, dapat disimpulkan bahwa kecerdasan spiritual santri Pondok Pesantren Mathla'unnajah Ujungjaya Sumedang sebesar $80 \%$ termasuk pada skala kategorisasi sangat tinggi.

\section{Pengaruh Intensitas Dzikir Ratib Al-Haddad terhadap Kecerdasan Spirtual Santri}

Terlebih dahulu dilakukan analisis pendahuluan untuk mempermudah penggolongan data statistik pada setiap pernyataan yang terdapat pada kuesioner. Adapun nilai setiap item pernyataan diberi skor sebagai berikut: a) Sangat Setuju (SS) $=5$ skor, b) Setuju (S) $=4$ skor, c) Netral (N) $=3$ skor, 4) Tidak Setuju (TS) $=2$ skor, dan 5)Sangat Tidak Setuju (STS) $=1$ skor.

Untuk memudahkan proses perhitungan data dengan SPSS (Statistical Pakcage for Social Science) 20.0 for windows maka dilakukan pengelompokan data berdasarkan jumlah setiap variabel seperti yang terdapat pada tabel berikut:

Tabel 1.2

$\sum$ Variabel $\mathbf{X}$ dan $\sum$ Variabel $\mathbf{Y}$

\begin{tabular}{lll}
\hline Responden & Intensitas Dzikir & Kecerdasan Spiritual \\
\hline 1 & 43 & 51 \\
2 & 44 & 51 \\
3 & 38 & 42 \\
4 & 42 & 50 \\
5 & 46 & 50 \\
6 & 41 & 41
\end{tabular}




\begin{tabular}{|c|c|c|}
\hline Responden & Intensitas Dzikir & Kecerdasan Spiritual \\
\hline 7 & 47 & 34 \\
\hline 8 & 36 & 36 \\
\hline 9 & 32 & 38 \\
\hline 10 & 42 & 46 \\
\hline 11 & 40 & 46 \\
\hline 12 & 39 & 44 \\
\hline 13 & 38 & 42 \\
\hline 14 & 41 & 50 \\
\hline 15 & 39 & 46 \\
\hline 16 & 29 & 44 \\
\hline 17 & 43 & 48 \\
\hline 18 & 36 & 37 \\
\hline 19 & 44 & 51 \\
\hline 20 & 45 & 44 \\
\hline 21 & 32 & 40 \\
\hline 22 & 48 & 44 \\
\hline 23 & 30 & 41 \\
\hline 24 & 23 & 30 \\
\hline 25 & 39 & 47 \\
\hline 26 & 42 & 45 \\
\hline 27 & 32 & 38 \\
\hline 28 & 41 & 43 \\
\hline 29 & 46 & 47 \\
\hline 30 & 46 & 51 \\
\hline 31 & 40 & 44 \\
\hline 32 & 48 & 44 \\
\hline 33 & 37 & 46 \\
\hline 34 & 35 & 37 \\
\hline 35 & 38 & 44 \\
\hline 36 & 40 & 45 \\
\hline 37 & 40 & 39 \\
\hline 38 & 46 & 48 \\
\hline 39 & 36 & 34 \\
\hline
\end{tabular}




\begin{tabular}{|c|c|c|}
\hline Responden & Intensitas Dzikir & Kecerdasan Spiritual \\
\hline 40 & 36 & 46 \\
\hline 41 & 37 & 50 \\
\hline 42 & 39 & 49 \\
\hline 43 & 40 & 43 \\
\hline 44 & 44 & 43 \\
\hline 45 & 37 & 42 \\
\hline 46 & 37 & 44 \\
\hline 47 & 38 & 45 \\
\hline 48 & 34 & 45 \\
\hline 49 & 31 & 40 \\
\hline 50 & 36 & 41 \\
\hline 51 & 46 & 49 \\
\hline 52 & 48 & 45 \\
\hline 53 & 44 & 43 \\
\hline 54 & 37 & 45 \\
\hline 55 & 46 & 47 \\
\hline 56 & 37 & 46 \\
\hline 57 & 39 & 44 \\
\hline 58 & 40 & 42 \\
\hline 59 & 45 & 48 \\
\hline 60 & 38 & 43 \\
\hline 61 & 41 & 43 \\
\hline 62 & 39 & 45 \\
\hline 63 & 38 & 45 \\
\hline 64 & 37 & 41 \\
\hline 65 & 38 & 47 \\
\hline 66 & 34 & 51 \\
\hline 67 & 41 & 45 \\
\hline
\end{tabular}

Sumber data: hasil pengolahan kuesioner

Data yang telah diperoleh kemudian dideskiripsikan secara rinci untuk masing-masing variabel. Pembahasan variabel dilakukan untuk menggunakan pendekatan kuantitatif, tujuannya adalah data yang diolah berbentuk angka atau skor ditafsirkan secara deskriptif. Data variabel yang dideskripsikan dalam 
penelitian ini yaitu variabel bebas atau variabel $\mathrm{X}$ (intensitas dzikir ratib alhaddad) dan variabel terikat atau variabel Y (kecerdasan spiritual santri).

Uji validitas dilakukan oleh peneliti agar setiap pernyataan yang diajukan dapat memenuhi syarat validitas sehingga dapat diterima sebagai instrumen yang layak digunakan dalam penelitian. Adapun menurut Sugiyono (2012: 121) kuesioner yang valid berarti instrumen tersebut dapat digunakan untuk mengukur apa yang seharusnya diukur. Pengujian yang dilakukan dalam penelitian ini menggunakan analisis statistik melalui perhitungan SPSS (Statistical Pakcage for Social Science) 20.0 for windows. Maka dapat dilihat hasil uji validitas variabel X (Intensitas Dzikir Ratib Al-Haddad) pada tabel 1.1 berikut:

Tabel 1.3

Uji Validitas Variabel X

\begin{tabular}{lllll}
\hline \multicolumn{2}{l}{ Item-Total Statistics } & & & \\
& $\begin{array}{l}\text { Scale Mean if Item Scale Variance if } \\
\text { Deleted }\end{array}$ & $\begin{array}{c}\text { Corrected Item- } \\
\text { Item Deleted }\end{array}$ & $\begin{array}{c}\text { Cotal Correlation } \\
\text { Tif Item Deleted }\end{array}$ \\
\hline P1 & 38,63 & 15,631 &, 633 &, 748 \\
P2 & 38,85 & 16,826 &, 590 &, 756 \\
P3 & 39,21 & 18,562 &, 341 &, 783 \\
P4 & 38,54 & 18,252 &, 458 &, 772 \\
P5 & 39,07 & 17,858 &, 492 &, 768 \\
P6 & 39,18 & 16,816 &, 597 &, 755 \\
P7 & 38,72 & 15,721 &, 609 &, 751 \\
P8 & 38,82 & 18,634 &, 397 &, 778 \\
P9 & 39,84 & 20,473 &,- 014 &, 828 \\
P10 & 38,91 & 18,234 &, 492 &, 770 \\
P11 & 38,00 & 19,000 &, 443 &, 776
\end{tabular}

Sumber: data hasil pengolahan kuesioner

Berdasarkan tabel di atas, $\mathrm{T}$ tabel yang digunakan $=0,2027$, maka hasil uji validitas dapat diketahui bahwa keseluruhan pernyataan yang terdiri dari 11 butir pernyataan variabel X (Intensitas Dzikir Ratib Al-Hadad) P1, P2, P3, P4, ...., P11 tersebut dinyatakan valid dan layak digunakan kecuali P9.

Setelah dilakukan uji validitas untuk seluruh item pada instrumen variabel $\mathrm{X}$ (intensitas dzikir ratib al-haddad), maka peneliti melakukan uji validitas terhadap variabel Y (kecerdasan spiritual santri) dengan menggunakan program SPSS versi 20 for windows yang telah dilakukan pada 67 sampel dari data yang telah diolah maka diperoleh data pada tabel 1.2 sebagai berikut:

Tabel 1.4

\section{Uji Validitas Variabel Y}




\begin{tabular}{lccccc}
\hline & $\begin{array}{c}\text { Scale } \\
\text { Mean } \\
\text { if Item } \\
\text { Deleted }\end{array}$ & $\begin{array}{c}\text { Scale } \\
\text { Variance } \\
\text { if Item } \\
\text { Deleted }\end{array}$ & $\begin{array}{c}\text { Item-Total Statistics } \\
\text { Corrected } \\
\text { Item-Total } \\
\text { Correlation }\end{array}$ & $\begin{array}{c}\text { Squared } \\
\text { Multiple } \\
\text { Correlation }\end{array}$ & $\begin{array}{c}\text { Cronbach's } \\
\text { Alpha } \\
\text { if Item } \\
\text { Deleted }\end{array}$ \\
\hline P1 & 46,76 & 18,154 &, 171 &, 270 &, 778 \\
P2 & 47,09 & 16,962 &, 529 &, 513 &, 746 \\
P3 & 47,19 & 16,977 &, 519 &, 469 &, 747 \\
P4 & 47,67 & 16,072 &, 510 &, 396 &, 744 \\
P5 & 48,00 & 18,152 &, 143 &, 208 &, 783 \\
P6 & 46,91 & 17,143 &, 360 &, 384 &, 760 \\
P7 & 46,63 & 17,450 &, 345 &, 460 &, 761 \\
P8 & 46,76 & 16,185 &, 486 &, 477 &, 746 \\
P9 & 47,12 & 16,137 &, 645 &, 478 &, 733 \\
P10 & 47,87 & 16,876 &, 368 &, 361 &, 759 \\
P11 & 47,36 & 16,112 &, 497 &, 440 &, 745 \\
P12 & 47,66 & 17,350 &, 279 &, 309 &, 769 \\
P13 & 47,85 & 17,099 &, 419 &, 353 &, 754
\end{tabular}

Sumber data: hasil pengolahan kuesioner

Berdasarkan tabel di atas, $T$ tabel yang digunakan $=0,2027$, maka hasil uji validitas dapat diketahui bahwa keseluruhan pernyataan yang terdiri dari 13 butir pernyataan variabel Y (Kecerdasan spiritual Santri) P1, P2, P3, P4, ...., P13 tersebut dinyatakan valid layak digunakan kecuali P1 dan P5.

Reliabilitas alat ukur kuesioner menunjukan sejauh mana instrumen yang digunakan tersebut dapat dipercaya. Instrumen yang reliabel adalah instrumen yang apabila digunakan beberapa kali untuk mengukur objek yang sama akan menghasilkan data yang sama. Dengan kata lain, reliabilitas menunjukan konsistensi suatu alat ukur dalam mengukur gejala yang sama. Uji reliabilitas ini juga dilakukan dengan menguunakan SPSS versi 20 for windows. Ujii reliabilitas ini diketahui dari besarnya Cronbach's alpha, dari hasil pengujian maka dapat diperoleh angka sebagai berikut:

Tabel. 1.5

Uji Reliabilitas Variabel X

\begin{tabular}{ll}
\hline Reliability Statistics \\
\hline Cronbach's Alpha & N of Items \\
\hline, 789 & 11
\end{tabular}

Sumber data: hasil pengolahan kuesioner 
Berdasarkan dari tabel di atas dapat diketahui bahwa Cronbach's Alpha variabel X (Intensitas Dzikir Ratib Al-Haddad) adalah 0.789. Dengan demikian dapat disimpulkan bahwa pernyataan variabel X (Intensitas Dzikir Ratib AlHaddad) dapat dikatakan reliabel karena $0.789 \geq 0.70$.

Tabel 1.6

\section{Uji Reliabilitas Variabel Y}

\begin{tabular}{lll}
\hline Reliability Statistics & \\
\hline Cronbach's Alpha & $\begin{array}{l}\text { Cronbach's Alpha N of Items } \\
\text { Based on Standardized } \\
\text { Items }\end{array}$ \\
\hline 771 &, 780 & 13
\end{tabular}

Sumber data: hasil pengolahan kuesioner

Berdasarkan tabel di atas dapat diketahui bahwa Cronbach's Alpha variabel Y (Kecerdasan Spiritual Santri) adalah 0.771. Dengan demikian dapat disimpulkan bahwa pernyataan variabel Y (Kecerdasan Spiritual Santri) dapat dikatakan reliabel karena $0.771 \geq 0.70$.

Data yang telah diperoleh melalui penyebaran kuesioner kemudian dianalisis dan dimuat dalam 21 pernyataan. Uji normalitas dilakukan untuk mengetahui data berdistribusi normal atau tidak dengan taraf signifikasi $\alpha=0.05$ $(5 \%)$. Dalam penelitian ini uji normalitas menggunakan uji Kolmogorv-Smirnov. Adapun hipotesis yang diajukan pada uji normalitas yaitu sebagai berikut:

\section{Hipotesis Statistik:}

$\mathrm{H}_{0} ; \mathrm{Pv} \geq 0.05$ maka residual berdistribusi normal.

$\mathrm{H}_{1} ; \mathrm{Pv} \leq 0.05$ maka residual tidak berdistribusi normal.

Analisis data tersebut dapat dilihat pada tabel berikut:

Tabel 1.7

\section{Uji Normalitas}

\begin{tabular}{ll}
\hline One-Sample Kolmogorov-Smirnov Test & $\begin{array}{l}\text { Unstandardized } \\
\text { Residual }\end{array}$ \\
\hline $\mathrm{N}$ & 67 \\
Normal Parameters & \\
&
\end{tabular}




\begin{tabular}{lll} 
& Std. Deviation & 3,85289730 \\
& Absolute &, 063 \\
Most Extreme Differences & Positive &, 054 \\
& Negative &,- 063 \\
Kolmogorov-Smirnov Z &, 512 \\
Asymp. Sig. (2-tailed) &, 955 \\
a. Test distribution is Normal. & \\
b. Calculated from data. & \\
\hline Sumber data: hasil pengolahan kuesioner &
\end{tabular}

\section{Kriteria Hipotesis :}

$\mathrm{Pv}>\propto$ maka $\mathrm{H}_{0}$ diterima

$\mathrm{Pv}<\alpha$ maka $\mathrm{H}_{1}$ ditolak

\section{Interpretasinya :}

Berdasarkan hasil output SPSS (Statistical Pakcage for Social Science) 20.0 for windows pada tabel di atas diperoleh $\mathrm{Pv}(0.955) \geq 0.05$. Maka $\mathrm{H}_{0}$ diterima, nilai residual tersebut normal atau dapat disimpulkan bahwa uji normalitas untuk kuesioner tersebut terpenuhi dan dapat disimpulkan bahwa data tersebut berdistribusi normal.

Langkah selanjutnya yaitu melakukan uji linearitas dengan hipotesis sebagai berikut:

\section{Hipotesis Statistik :}

$\mathrm{H}_{0}$ : Model regresi linear sederhana tidak dapat digunakan dalam memprediksi peningkatan kecerdasan spiritual santri Pondok Pesantren Mathla'unnajah Ujungjaya Sumedang yang dipengaruhi intensitas dzikir ratib al-haddad.

$\mathrm{H}_{1} \quad$ : Model regresi linear sederhana dapat digunakan dalam memprediksi peningkatan kecerdasan spiritual santri Pondok Pesantren Mathla'unnajah Ujungjaya Sumedang yang dipengaruhi intensitas dzikir ratib al-haddad.

Taraf signifikan $\alpha=0.05 \mathrm{Y}=\mathrm{a}+\mathrm{bX}=$ $\mathrm{Y}=26.680+0.442(67)$ $=56.294$

Tabel. 1.8

Uji Linearitas

\begin{tabular}{ccccc}
\hline ANOVA Table & \multicolumn{3}{c}{ Sum of SquaresdfMean SquareF } & Sig. \\
\hline \multirow{3}{*}{$\mathrm{Y}^{*} \mathrm{X}$} & (Combined) & 914,578 & 1948,136 & $5,866,000$ \\
& 320,511 & 1320,511 & $39,057,000$ \\
Within Groups & Deviation from Linearity594,067 & 1833,004 & $4,022,000$ \\
& 385,690 & 478,206 &
\end{tabular}


Total

Sumber data: hasil pengolahan kuesioner
$1300,269 \quad 66$

\section{Kriteria Hipotesis :}

$\mathrm{P}_{\mathrm{V}}>\alpha$ maka $\mathrm{H}_{0}$ diterima

$\mathrm{PV}<\alpha$ maka $\mathrm{H}_{1}$ ditolak

\section{Interpretasinya :}

Karena $\mathrm{Pv}_{\mathrm{v}}<0.05$ maka $\mathrm{H}_{0}$ DITOLAK sehingga Model regresi linear sederhana dapat digunakan dalam memprediksi peningkatan kecerdasan spiritual santri Pondok Pesantren Mathla'unnajah Ujungjaya Sumedang yang dipengaruhi intensitas dzikir ratib al-haddad.

$\mathrm{Y}=26.680+0.442 \mathrm{X}$

Konstanta (a) $=26.680$

Artinya : Apabila intensitas dzikir ratib al-haddad sama dengan nol (tidak ada perubahan ), maka kecerdasan spiritual santri sebesar 0.442 .

Koefisien Regresi Intensitas Dzikir Ratib Al-Haddad (b) $=0.442$

Artinya : Koefisien regresi postif ( searah ) sebesar 0.442. Jika intensitas dzikir ratib al-haddad meningkat 1 satuan, maka kecerdasan spiritual santri sebesar 0.442 yang berarti jika intensitas dzikir ratib al-haddad naik sebesar 1,329 maka kecerdasan spiritual santri akan naik sebesar 0.442.

Pengujian hipotesis ini dimaksudkan untuk mengetahui apakah ada atau tidak pengaruh yang signifikan antara variabel $\mathrm{X}$ terhadap variabel $\mathrm{Y}$. Untuk menguji pengaruh intensitas dzikir ratib al-haddad terhadap kecerdasan spiritual santri Pondok Pesantren Mathla'unnajah Ujungjaya Sumedang. Maka dilakukan pengujian hipotesis parsial (uji t), yaitu dengan membandingkan t tabel dengan $\mathrm{t}$ hitung.

\section{Hipotesis Statistik:}

$\mathrm{H}_{0}: \mathrm{b}_{1}=0$; Tidak terdapat pengaruh intensitas dzikir ratib al-haddad (X) terhadap kecerdasan spiritual santri (Y) Pondok Pesantren Mathla'unnajah Ujungjaya Sumedang.

$\mathrm{H}_{1}: \mathrm{b}_{1} \neq 0$; Terdapat pengaruh intensitas dzikir ratib al-haddad $(\mathrm{X})$ terhadap kecerdasan spiritual santri (Y) Pondok Pesantren Mathla'unnajah Ujungjaya Sumedang.

Taraf signifikasi $\alpha=0.05$.

Tabel. 1.9

\section{Uji Hipotesis}

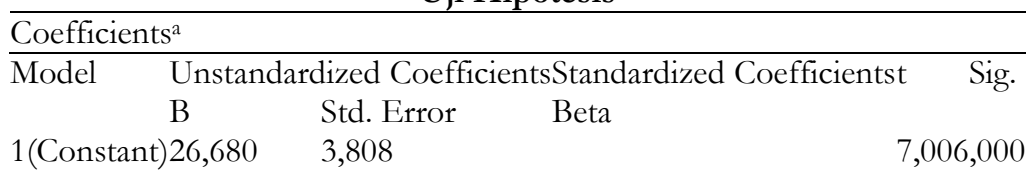

Irsyad : Jurnal Bimbingan, Penyuluhan, Konseling, dan Psikoterapi Islam 7(1) (2019) 61-84 
M. Maesaroh

$\begin{array}{cccc}\mathrm{X} & , 442 \quad, 096 & , 496 & 4,611,000 \\ \text { a. Dependent Variable: } Y & \end{array}$

Sumber data: hasil pengolahan kuesioner

\section{Kriteria Hipotesis :}

$\mathrm{H}_{0}$ diterima dan $\mathrm{H}_{1}$ ditolak, jikar $\mathrm{t}$ hitung $\geq \mathrm{t}$ tabel artinya variabel $\mathrm{X}$ tidak mempengaruhi variabel $\mathrm{Y}$ secara signifikan.

$\mathrm{H}_{0}$ ditolak dan $\mathrm{H}_{1}$ diterima, jika $\mathrm{t}$ hitung $\leq \mathrm{t}$ tabel artinya variabel $\mathrm{X}$ mempengaruhi $Y$ secara signifikan.

\section{Interpretasinya :}

Nilai t hitung untuk variabel intensitas dzikir ratib al-haddad $(\mathrm{X})$ adalah sebesar 4.611 dan nilai $\mathrm{t}$ tabel adalah 2.027, sehingga $\mathrm{t}$ hitung $\geq \mathrm{t}$ tabel $(4.611 \geq$ 2.027) dengan tingkat signifikasi berdasarkan perhitungan SPSS (Statistical Pakcage for Social Science) 20.0 for windows diperoleh $0.000 \leq 0.05$. Karena $\mathrm{Pv}<$ 0.05 maka $\mathrm{H}_{0}$ DITOLAK sehingga Terdapat pengaruh positif intensitas dzikir ratib al-haddad terhadap kecerdasan spiritual santri Pondok Pesantren Mathla'unnajah Ujungjaya Sumedang.

Uji regresi linear sederhana bertujuan untuk mengukur seberapa besar pengaruh variabel X (Intensitas Dzikir Ratib Al-Haddad) terhadap variabel Y (Kecerdasan Spiritual Santri) secara linear. Berdasarkan hasil perhitungan SPSS (Statistical Pakcage for Social Science) 20.0 for window diperoleh data sebagai berikut:

Tabel 1.10

Uji Regresi Linear Sederhana

\begin{tabular}{|c|c|c|c|c|}
\hline \multicolumn{5}{|c|}{$\overline{\text { Model Summary }}{ }^{\mathrm{b}}$} \\
\hline$\overline{\text { Model }}$ & $\mathrm{R}$ & R Square & Adjusted R Square & $\begin{array}{l}\text { Std. Error of the } \\
\text { Estimate }\end{array}$ \\
\hline 1 &, $496^{a}$ & ,246 & ,235 & 3,882 \\
\hline \multicolumn{5}{|c|}{ a. Predictors: (Constant), X } \\
\hline
\end{tabular}

Sumber data: hasil pengolahan kuesioner 
R Square $=0.246$

\section{Interpretasinya :}

Berdasarkan tabel di atas, nilai $\mathrm{R}$ merupakan simbol dari nilai koefisein korelasi. Pada tabel di atas nilai korelasi adalah 0.496. Nilai ini dapat diinterpretasikan bahwa hubungan kedua variabel penelitian ada pada kategori cukup kuat. Melalui tabel ini juga diperoleh nilai $\mathrm{R}$ Square atau koefisien determinasi (KD) yang menunjukan berapa besar model regresi yang dibentuk oleh interaksi variabel bebas dan variabel terikat. Nilai koefisien determinasi (KD) yang diperoleh adalah $0.246 \times 100 \%=24.60 \%$ yang dapat ditafsirkan bahwa variabel bebas atau variabel $\mathrm{X}$ (Intensitas Dzikir Ratib Al-Haddad) memiliki pengaruh sebesar $24.60 \%$ terhadap variabel terikat atau variabel $\mathrm{Y}$ (Kecerdasan Spiritual Santri) dan 75.40\% lainnya dipengaruhi oleh faktor-faktor lain di luar variabel $\mathrm{X}$.

\section{PENUTUP}

Berdasarkan hasil penelitian tentang pengaruh intensitas dzikir ratib al-haddad terhadap kecerdasan spiritual santri Pondok Pesantren Mathla'unnajah Ujungjaya Sumedang, maka dapat disimpulkan sebagai berikut:

Intensitas dzikir ratib al-haddad yang dilakukan oleh santri Pondok Pesantren Mathla'unnajah Ujungjaya Sumedang berdasar pada jawaban responden sebanyak 67 santri diperoleh hasil rata-rata presentase sebesar $79 \%$. Hal ini menunjukan bahwa intensitas dzikir ratib al-haddad berada dalam keadaan baik sesuai dengan jawaban yang diberikan oleh responden yang menghasilkan nilai 79\% yang berada pada presentase skor $60 \%$ - 79\% dengan skala kategori tinggi.

Kecerdasan spiritual santri berdasar pada jawaban responden di Pondok Pesantren Mathla'unnajah Ujungjaya Sumedang sebanyak 67 santri dengan diperoleh nilai hasil kriteria rata-rata presentase sebesar 80\%. Hal ini menunjukan bahwa kecerdasan spiritual santri berada dalam keadaan sangat baik sesuai dengan jawaban yang diberikan oleh responden yang menghasilkan nilai $80 \%$ yang berada pada presentase skor $80 \%$ - 100\% dengan skala kategori sangat tinggi.

Pengaruh intensitas dzikir ratib al-haddad terhadap kecerdasan spiritual santri Pondok Pesantren Mathla'unnajah Ujungjaya Sumedang memiliki nilai 0.246 atau $24.60 \%$ dengan kategorisasi rendah karena berada pada interval koefisien 0.20-0.399. Dapat ditafsirkan bahwa variabel X (Intensitas Dzikir Ratib Al-Haddad) memiliki pengaruh sebesar $24.60 \%$ terhadap variabel Y (Kecerdasan Spiritual Santri) dan $75.40 \%$ lainnya dipengaruhi oleh faktor-faktor lain di luar variabel X, diantaranya: Pertama, inner value (nilai-nilai spiritual dari dalam) yang 
berasal dari dalam diri (suara hati) seperti transparency (keterbukaan), responsibilities (tanggung jawab), accountabilities (kepercayaan), fairness (keadilan), dan social wareness (kepedulian sosial). Kedua, drive adalah dorongan atau usaha untuk mencapai kebenaran dan kebahagiaan.

Berdasarkan hasil output SPSS (Statistical Pakcage for Social Science) 20.0 for windows pada tabel di atas diperoleh $\mathrm{Pv}(0.955) \geq 0.05$. Maka $\mathrm{H}_{0}$ diterima, nilai residual tersebut normal atau dapat disimpulkan bahwa uji normalitas untuk kuesioner tersebut terpenuhi dan dapat disimpulkan bahwa data tersebut

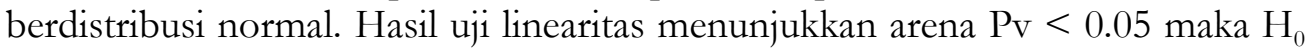
ditolak sehingga Model regresi linear sederhana dapat digunakan dalam memprediksi peningkatan kecerdasan spiritual santri Pondok Pesantren Mathla'unnajah Ujungjaya Sumedang yang dipengaruhi intensitas dzikir ratib alhaddad.

Hasil uji hipotesis menunjukkan bahwa Nilai t hitung untuk variabel intensitas dzikir ratib al-haddad (X) adalah sebesar 4.611 dan nilai t tabel adalah 2.027, sehingga t hitung $\geq \mathrm{t}$ tabel $(4.611 \geq 2.027)$ dengan tingkat signifikasi berdasarkan perhitungan SPSS (Statistical Pakcage for Social Science) 20.0 for windows diperoleh $0.000 \leq 0.05$. Karena $\mathrm{Pv}<0.05$ maka $\mathrm{H}_{0}$ DITOLAK sehingga Terdapat pengaruh positif intensitas dzikir ratib al-haddad terhadap kecerdasan spiritual santri Pondok Pesantren Mathla'unnajah Ujungjaya Sumedang.

Sedangkan hubungan antara intensitas dzikir ratib al-haddad terhadap kecerdasan spiritual santri Pondok Pesantren Mathla'unnajah Ujungjaya Sumedang memiliki nilai $\mathrm{t}=0.496$. Sehingga dapat penulis simpulkan bahwa hubungan antara intensitas dzikir ratib al-haddad terhadap kecerdasan spiritual santri Pondok Pesantren Mathla'unnajah Ujungjaya Sumedang memiliki hubungan yang cukup kuat, karena nilai $\mathrm{t}=0.469$ berada pada interval koefisien $0.40-0.599$ dengan kategori cukup kuat.

\section{DAFTAR PUSTAKA}

Al Islam. (1987). Muamalah dan Akhlak. Jakarta: Rineka Cipta.

Al-Husaini, A. A. A. (Diterjemahkan oleh Rosihon). (1999). Sentuhan-sentuhan Sufistik: (Penuntun Jalan Akhirat) pustaka Setia: Bandung.

Al-Kaff, I. A. (2003). Bisikan-bisikan Ilahi; Pemikiran Sufistik Imam al-Haddad dalam diwan ad-Duar al-Manzhum. Pustaka Hidayah IKAPI: Bandung.

Amin, S. M. (2008). Energi Dzikir. Jakarta: Bumiaksara.

Ansori, A. (2003). Dzikir dan Kedamaian Jiwa. Yogyakarta: Purtaka Pelajar.

Departemen Pendidikan dan Kebudayaan. (1988). Kamus Besar Bahasa Indonesia. Jakarta: Balai Pustaka.

Desmita. (2010). Psikologi Perkembangan Peserta Didik. Bandung: Pustaka Setia.

Kurniasih, I. (2010). Mendidik SQ Anak Menurut Nabi Muhammad SAW. 
Yogyakarta: Pustaka Warna.

Madjid, N. (1997). Bilik-bilik Pesantren, Sebuah Potret Perjalanan. Jakarta: Paramadina.

Marshall, D Z. (2007). Memanfaatkan Kecerdasan Spiritual dalam Berfikir Integralistik dan Holistik untuk Memaknai Kehidupan. Jakarta: Pustaka Mizan.

Noupal, M. (2018). Zikir Ratib Haddad: Studi Penyebaran Tarekat Haddadiyah di Kota Palembang dalam Intizar 24(1) 103-114.

Rahmawati, U. (2016). Pengembangan Kecerdasan Spiritual santri: Studi terhadap Kegiatan Keagamaan di Rumah TahfizQu Deresan Putri Yogyakarta dalam Jurnal Penelitian 10(1) 97-124.

Sugiyono. (2011). Metode Penelitian Kualitatif Kuantitatifdan R\&D, Bandung: Alfabeta.

Wahyudin, A. (2015). Spiritualitas Cyberspace; Interplay Post Sains-Teknologi dengan Spiritualitas Sains Dakwah. Ilmu Dakwab: Academic Joumal For Homiletic Studies, $\quad 5(17), \quad 347 \quad$ - 376. doi:http://dx.doi.org/10.15575/idajhs.v5i17.370

Zamakhsyary, D. (2011). Tradisi Pesantren: Studi tentang Pandangan Hidup Kyai. Jakarta: LP3ES. 
M. Maesaroh 